\title{
自然環境の厳しい漁港における入港問題について \\ Ship Entry Problems at Fishery Harbors under Severe Weather Condition
}

久保 雅義 $^{*} \cdot$ 水井 真治 ${ }^{* *} \cdot$ 斎藤 $\quad$ 勝彦 ${ }^{*}$

\author{
Masayoshi KUBO, Shinji MIZUI and Katsuhiko SAITO
}

\begin{abstract}
For a design of Marine Guide Fence, two step questionnaires are conducted to users of fishery harbors under severe weather condition. The obtained results are summarized as follows:

(1) The thresholds of wind speed and wave height at ship entry into harbors vary by each fishery harbor.

Particularly the limit of wave height shows wide variation from $1.5 \mathrm{~m}$ to $5 \mathrm{~m}$.

(2) Wave group near the harbor entrance has a kind of regularity and fishermen manoeuvre their ship so that they can pass through the entrance when the waves are small.

(3) Fishermen think more of wave conditions than wind ones in entering into a harbor.

(4) The distribution of degree of fishermen's tension and relief at harbor entrance shows single sharp peak for the harbor with only main and sub breakwaters, on the other hand it shows flat for the harbors with many breakwaters due to wave attenuation at the entrance. If the distance between the entrance and the most tense position is converted to the ship length, it is $(5 \sim 7) L$.

(5) The ship speed under strong wind and waves is approximately $3.5 \sim 6.0$ knots with the cumulative relative frequency of $0.2 \sim 0.8$.

(6) Under severe weather condition, almost fishing boats slow down near the entrance. However, at the harbor where boats receive against wind and waves, they speed up and pass through the entrance quickly.
\end{abstract}

\section{1. 緒 言}

わが国は、冬期風浪の厳しい日本海側、台風時のうねりの強い太平洋側に代表されるように、港湾、 特に漁港においては厳しい自然環境であり、その対策としてこれまで膨大な量の防波堤が建設されてきた。 これまでの防波堤建設により、港内の波を静穏にし、船の係留を安全にすることはある程度達成された かに見える。しかしながら、船が入港するときは、狭い港口部を入港することになり、特に荒天時にお いては防波堤が入港の障害となっている場合でさえ存在する。

そこで、著者らはこうした自然環境の厳しい港沙及び漁港において、入港時の安全確保のために狭い港 口部を安全に航過させ、また防波堤等の構造物への衝突を防止、もしくは港口部における変針補助の目 的で「船舶入港支援施設」(以降「ガイド」と略称する。)の設置を提案している。ガイドの機能については、 これまでの模型実験及び数値シミュレーション(1) (4)により基本機能が明らかになり、現在、試設計段階に

* 正会員 神戸商船大学 ( $\mathbf{T} 658$ 神戸市東灘区深江南町 5-1-1)

** 正会員 広島商船高等専門学校 ( $7725-02$ 広島県豊田郡東野町 $4272-1$ ) 
入っている。

よって、本研究では、入港困難度の高い漁港において、ガイド試設計を行うために、今まで明らかに なっていない、設計条件に関連する内容を現場の実務者に対してアンヶート調查を行い、今後のガイド 試設計に役立てられるように漁民の意見を聴取した。

\section{2. 調査の方法}

著者らは、漁港の入港問題の実態を捉え、地域性 が存在することを明らかにした全国レベルのアン ケート調查 ${ }^{(5)}$ を実施した。この全国の第 2 種以上の 漁港を対象とした前回のアンケート調查に回答の寄 せられた漁港の内、ガイド試設計に役立てるために、 特に入港条件の㛜しい之考えられる入港困難回数が 年間 20 回以上の 23 漁港の漁業協同組合を通じて以 下のようなアンケート調查を実施した。

調查は、この 23 漁業協同組合の組合長に対し協 力意志の確認と 5 年以上の運航経験を有する実務者 の選定を依頼した第 1 次アンケートを実施した。ま た、第 1 次アンケートでは、図 1 に示すような各 漁港に打ける標準的な入港針路の確認等を行い 18 漁業協同組合より協力の回答が寄せられた。

そこで、18 漁業協同組合を通じて、表 1 に示す 第 2 次アンケートを実施した。「回答者の所有船に ついて」の質問項目では、回答者の経験年数及び自 身の所有船の大きさ等をたずね、「入港限界条件」、 「港口付近における波の連なり方の特性」の項目で は、ガイドの試設計に役立てる上で重要な、入港 できなくなると感じる限界風速・限界波高及び入港 が危険となるようなシケの際の波の連なり方とその 時の操船方法をたずねた。また、「入港問題の要 因」の項目では、入港が危険となる要因をたずねた。 「入港時の速力」、「操船上の緊張度と安心度」の 項目では、標準コースを 16 分割した位置番号ごと に波浪のない状態と波浪のある状態(入港限界に近 い波高がある状態：以降「シケている状態」と略称 する。）における速力の回答及び操船上最も緊張す る位置番号、安心感を抱き始める位置番号の回答を お願いした。最後に、「横傾斜角」の項目では、今 まで経験した最大横傾斜角等についてたずねた。

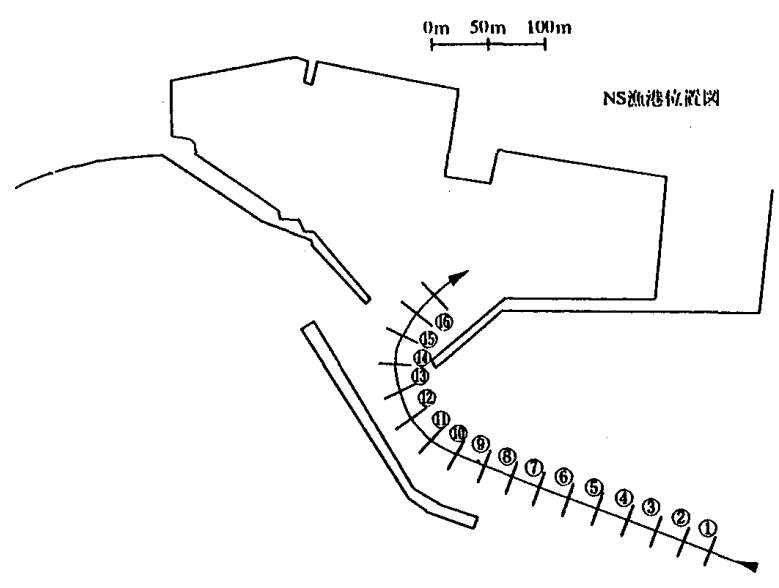

図 1 アンケートに使用した漁港位置図の例

表 1 主なアンヶートの内容

\begin{tabular}{|c|c|}
\hline Trifox & 回䬭内突 \\
\hline 回答者の所有粕について & $\begin{array}{l}\text { 総卜ン数、全長、幅、満戟吃水、沖で } \\
\text { の航海速力等 }\end{array}$ \\
\hline 入港限界条件 & $\begin{array}{l}\text { 限界風速、限界波高、入港できなくな } \\
\text { る波高 }\end{array}$ \\
\hline $\begin{array}{l}\text { 港口付近における波の運な } \\
\text { 方の特性 }\end{array}$ & $\begin{array}{l}\text { 大きい波と小さい波の連なり方 } \\
\text { 荒芺時の操船方法 }\end{array}$ \\
\hline 入港問題の要因 & 要因ごとに選択回答 \\
\hline 捰船上の製張度および安心 & 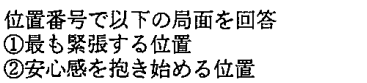 \\
\hline 入浩時の速力 & 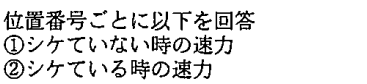 \\
\hline 拱值科角 & 今までに経験した最大横順斜角 \\
\hline
\end{tabular}

\section{3. 回答率と調查対象}

表 2 に第 1 次アンケートに回答のあった漁港名ごとの第 2 次アンケートの発送数と回答数を示す。表 2 に示すとおり、漁港毎に少なくとあ回答数が約 20 以上の漁港のべ 316 人のアンヶートを今回の調查対象 とし、各漁港ごとの入港問題を検討することとした。 


\section{4. 調査結果}

\section{1 入港限界}

\subsection{1 限界風速之限界波高}

各漁港ごとに入港できないと感じる限界風速と限 界波高は、相当バラッキがあり、前回の全国アン ケート (5)ですでに明らかになっているょうに地域特 性が存在しているようである。

図 2 と図 3 は、入港できないと感じる限界風速及 び限界波高を示した事例である。図 2 は、漁船の大 きさと限界波高の関係を示し、図中 $T N$ 漁港は、平 均限界波高が最も高い例であり、NA 漁港は、同波 高が最も低い例を示している。船の大きさの違いに よる感じ方の差異は、必ずしも明確ではなく、限 界波高は、 $1.5 \mathrm{~m} \sim 5 \mathrm{~m}$ の範囲を回答している。これ は、例えば $T N$ 漁港は向かい波、NA 漁港は追い波 が波浪の主方向となっており、波向の違いが関係し ているようである。

図 3 は、漁船の大きさ之限界風速の関係を示し、 図中 $S I$ 漁港は、平均限界風速が最も高い例であり、 $N A$ 漁港は同風速が最も低い例を示している。12 漁 港で約 $10 \sim 30 \mathrm{~m} / \mathrm{s}$ の範囲を回答し、船の大きさと の相関は必ずしも明確ではない。限界風速及び限界 波高は、漁港毎に入港できないと感じる数值に相当 バラッキがあり、今回の調查において、その理由 は明らかにならなかった。

4.1.2 港口付近の波の連なり方の特性と操船方法

図 4 は第 1 次及び第 2 次アンケートを実施した 23 漁港等の港口付近の大きい波と小さい波の連な り方の表現を日本全図にまとめたあのである。この 項目についてのみ特に、回答を依頼し、合わせて 27 漁港中 24 港から回答を得ることができた。その 結果、シヶの際に、この 24 漁港中 22 港は波の連な り方に何らかの規則性があるとの回答が寄せられた。 残りの 2 港は、特に大きい波と小さい波の規則性は ないようである。また、シケの際の港口付近の操船 方法は、ほとんどの漁港においてシケの入港時、 波の大小を予測しながら港口で波が小さい時に通過 できるように、減速等を行いながら操船しているこ とが明らかになった。波浪中における操船方法の代 表例を以下にまとめる。

(日本海沿岸の $K Z$ 漁港の例)

・「波のあいまを見る」という表現がされており、 3 大 4 小の波に近いシヶの入港時、大きい波の 次の小さい波の合間に入港できるような操船を 行っている。
表 2 第 2 次アンケートの回答率

\begin{tabular}{|c|c|c|c|}
\hline 漁港略号 & 発送数 & 回答数 & 回答率 \\
\hline S.I. & 40 & 36 & 90.00 \\
\hline K 2 & 32 & 29 & 90.63 \\
\hline $7 P$ & 36 & 3. & 88.57 \\
\hline N.S. & 45 & 24 & 53.38 \\
\hline A R & 30 & 25. & 83.38 \\
\hline T N & 50. & 38 & 76.00 \\
\hline N A & 30. & 30 & 100.00 \\
\hline 11 & 30 & 20 & 66.67 \\
\hline AO & 30. & 19 & 63.33 \\
\hline YE & 33 & 28 & 69,70 \\
\hline $\mathrm{KM}$ & 35 & 20 & 57.14 \\
\hline ND & 30 & 21 & 70.00 \\
\hline$S R$ & 28 & 14 & 50.00 \\
\hline$T \cup$ & 30 & 14 & 46.67 \\
\hline $1 \mathrm{~s}$ & 50 & 12 & 24.00 \\
\hline TD & 30 & 5 & 16.67 \\
\hline M T & 30 & 11 & 36.67 \\
\hline TK & 35 & 5 & 14.29 \\
\hline 合計 & 623 & 377 & \\
\hline
\end{tabular}

\section{今回の調查対象}

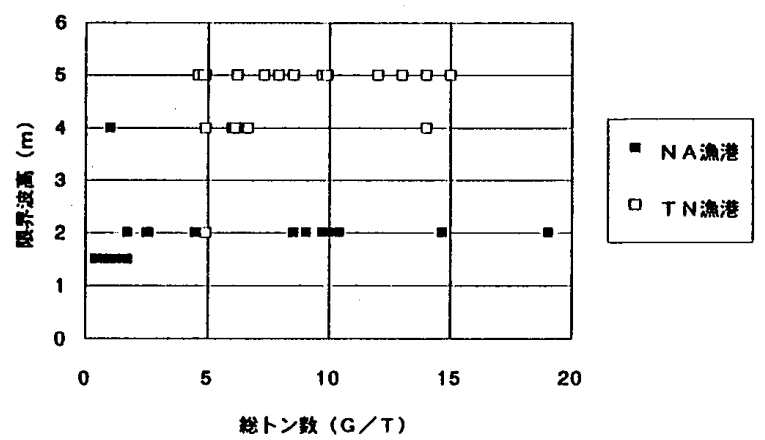

図 2 漁船の大きさ之限界波高の関係 ( $N A$ 漁港と $T N$ 漁港の例)

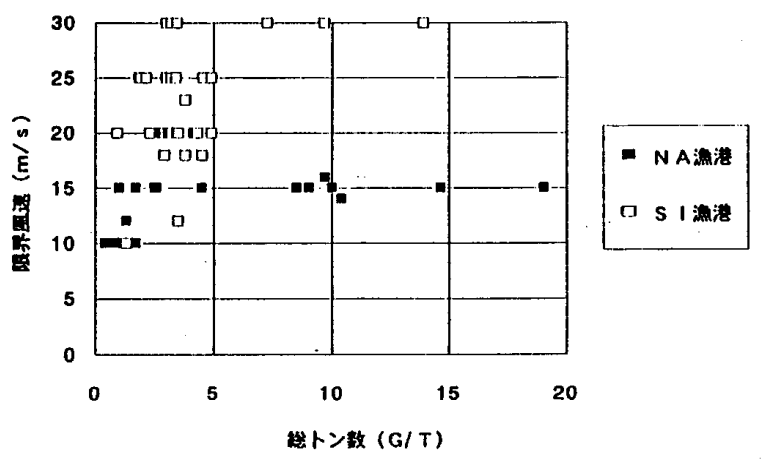

図 3 漁船の大きさと限界風速の関係 ( $S I$ 漁港と $N A$ 漁港の例 ) 
・港口付近で減速するが、一定回転数以

下に落とすと船体後方からのうねりに よって舵が効かなくなるので、徐々に 減速しながら入口で小さい波になるよ うに予测する。

(北海道沿岸の $S R$ 漁港の例)

・「大きい波は、3 枚来て、間がある。」 という表現をされており、3大 4 小中 4 の連なり方のうねりの小さい波の間 に入港できるように港口付近を操船し ている。

これらの例のように、実務者は、波浪中 港口付近において、小さい波で通過できる よう予測しながら運航しており、このこと はガイド設計時の対象波を決定する上で、 必ずしも最大波とする必要がない等参考に なると考えられる。

\section{2 入港問題の要因}

港口付近で入港時に、風波により保針で きない等種々の問題が起きているが、表 3 はその要因を $5 つ$ 選択肢からの複数回答 を各漁港ごとに、集計整理したものである。 これょり、全ての漁港において「風による 保針困難」はそれ程重要視していないこと がわかり、全国アンケートより以上に明確 な傾向があった。

表 3 に示すとおり、回答 2 の港口付近の 「波による保針困難」が全回答の約 40\%を 占め最も多く、回答 3 と合わせれば風より、 波による入港問題を重要と考えているよう である。回答 3 の港口付近での「波による 船体傾斜などによる転覆の危険性」は、例 外を除いて港口部での入港コースと位置番

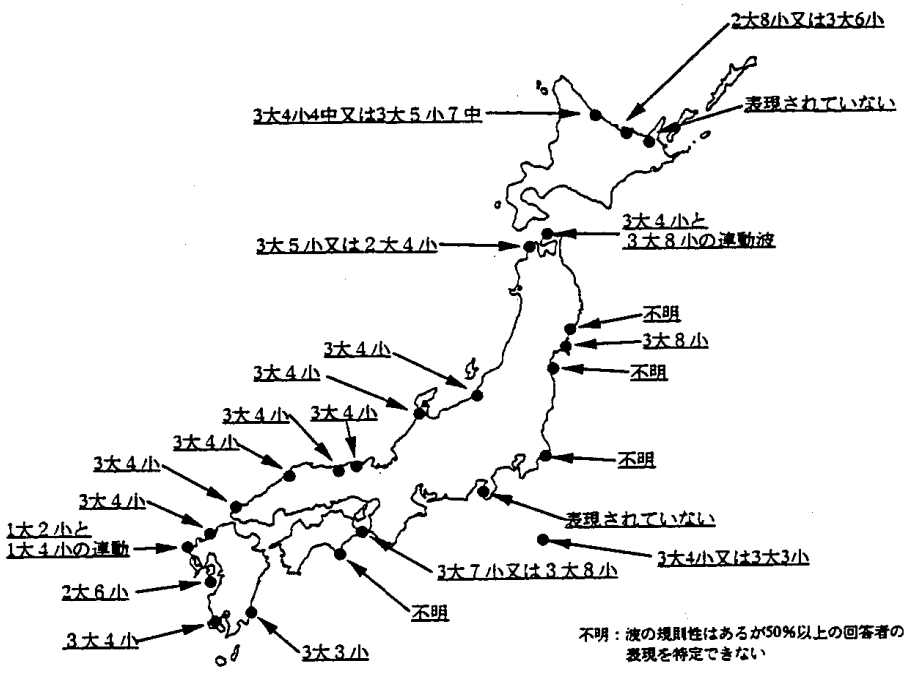

図 4 各漁港ごとの波の連なり方の特性について

表 3 入港問題の要因についての集計結果

\begin{tabular}{|c|c|c|c|c|c|c|c|}
\hline 漁港螵号 & 回答1 & 回答2 & 回答3 & 回答4 & 回答5 & 変鱽角(deg) & 呯俩 \\
\hline$T P$ & 0 & 31 & 0 & 0 & 0 & 10 & G1 \\
\hline $\mathrm{NS}$ & 6 & 18 & 4 & 5 & 6 & 122 & G1 \\
\hline s I & 0 & 32 & 15 & 9 & 4 & 0 & G1 \\
\hline $\mathrm{KZ}$ & 6 & 17 & 23 & 12 & 5 & 40 & $\mathrm{G} 2$ \\
\hline NA & 1 & 29 & 29 & 3 & 0 & 62 & $\mathrm{G} 2$ \\
\hline$T N$ & 0 & 16 & 23 & 0 & 0 & 162 & G2 \\
\hline$A O$ & 3 & 13 & 18 & 7 & 1 & 96 & G2 \\
\hline $1 \mathrm{~J}$ & 1 & 6 & 8 & 19 & 0 & 85 & G3 \\
\hline$A R$ & 3 & 8 & 8 & 22 & 2 & 15 & G3 \\
\hline YE & 0 & 10 & 4 & 9 & 0 & 0 & \\
\hline ND & 0 & 7 & 9 & 5 & 0 & 38 & \\
\hline$K M$ & 5 & 5 & 7 & 1 & 3 & 30 & \\
\hline \multicolumn{8}{|c|}{ 回答1：風により入港時の保虫困醀 } \\
\hline & \multicolumn{7}{|c|}{ 回答2：波により入港時の保䌶困期 } \\
\hline & \multicolumn{7}{|c|}{ 回答3：港口付近において船体の大きな㮌科 } \\
\hline & \multicolumn{7}{|c|}{ 回答4：港口付近において防波堤等に筍突の危除性 } \\
\hline & \multicolumn{7}{|c|}{ 回答5 : その他 } \\
\hline & G1: & \multicolumn{6}{|c|}{ : 回答2の副合が䯩い漁港 } \\
\hline & G2: & \multicolumn{6}{|c|}{ : 回答2及ひ3の割合の高い漁港 } \\
\hline & G3 & & & & & & \\
\hline
\end{tabular}

号 1 のコースとの角度すなわち变針角が大きい漁港程、回答の割合が高い傾向にある。このことは、变針 による外方傾斜と波による船体傾斜等の危険性が重複しているあのと考えられる。

また、表 3 に示した評価項目は、波による保針困難を問題としている漁港、これに加えて波による船 体傾斜による転覆の危険性を問題としている漁港及び港口における防波堤等衝笑の危険性を問題としてい る漁港の $G 1 \sim G 3$ 等に分類できることを示している。

4.3 操船に打ける緊張度と安心度について

各漁港ごとの操船上最む緊張する位置及び安心感を抱き始める位置の相対頻度 $P_{i}$ を求めた。ここで、 $P_{i}$ は次式により算定する。

$$
\begin{aligned}
& P_{i}=i \text { 位置番号の回答数/全体回答数 } \\
& \sum_{i=1}^{16} P_{i}=1.0
\end{aligned}
$$

表 4 は各漁港におけるアンケート集計を基に港口より外方を正、港口より内方を負にとり緊張度と安心 度各々について港口からの距離平均値之標準偏差及びこの平均值と平均船長 $L(\mathrm{~m})$ の比を示している。例 
えば、緊張度については、この距離平均值 $D_{t}$ と標 準偏差 $\sigma_{t}$ は次式により算定できる。

$$
\begin{aligned}
D_{t} & =\sum_{i=1}^{16}\left(P_{i} \cdot D_{i}\right) \cdots \cdots \cdots \cdots \cdots \cdots \cdots \cdots(2) \\
\sigma_{t} & =\sqrt{\sum_{i=1}^{16}\left\{\left(D_{i}-D_{t}\right)^{2} \cdot P_{i}\right\}} \cdots \cdots(3) \\
D_{i} & \text { : 各位置番号ごとの港口までの距離 }
\end{aligned}
$$

安心度についてあ同様に $D_{r} 、 \sigma$, の算定を行った。

以上の算定集計である表 4 より、実務者が最あ緊 張する位置は、平均船長の比に換算すると $5 L \sim 7 L$ にほぼピークがある。これに比べ安心度のピークは、 各漁港で相当バラッキがある。これは、港口ょり岸 壁までの距離、港内変針の有無等に関係があり、 また漁港の形状により異なるが、最も安心感を抱く のは港口通過直後または港口でほぼ変針動作を完了 表 4 各漁港の緊張度及び安心度に関する算定結果 した位置のようである。

図 5 図 8 は、この緊張度、安心度の分布を表した代表事例であり、図中分布の横軸は位置を、縦軸は 相対頻度 $P_{i}$ を表している。図 5 の $K Z$ 漁港及び図 6 の $A R$ 漁港の事例は防波堤配置の複雑さ及び港口部 の長さ、更に変針動作の回数の多さ等により緊張度、安心度いずれあ相当幅のある分布形状となってい る。

一方、図 7 の $T P$ 漁港及び図 8 の $T N$ 漁港の事例では、対照的に港口手前で一度に緊張度のピークがあ り、港口通過直後に安心度がピークとして現れている。他の漁港も、いずれかのパターンもしくは中間的 パターンに分類できる。これらの事例は、入港操船する実務者の意識をよく表している。今後のガイド現 地実験において、こうした実務者の緊張度が高いと考えている場所は、ガイドの設置位置として参考と なるあのと考えられる。

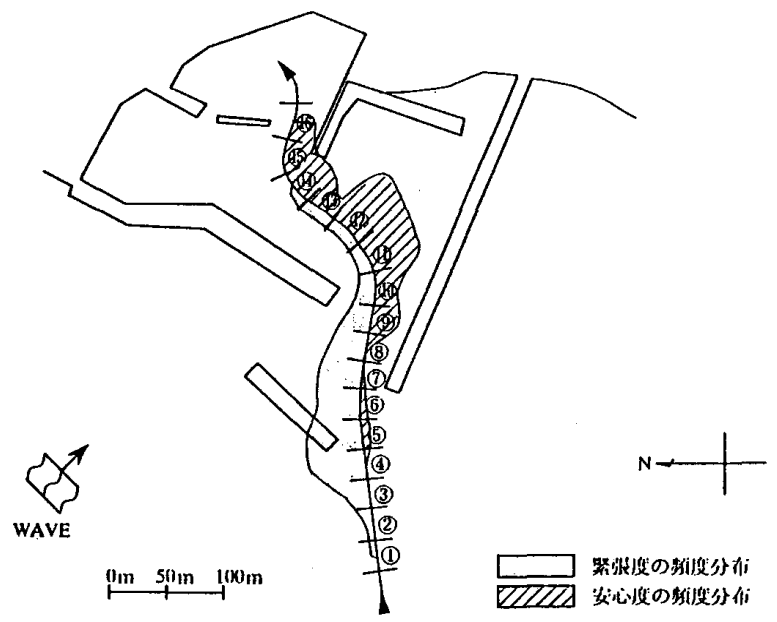

図 5 入港操船における緊張度と安心度 ( $K Z$ 漁港の例 )

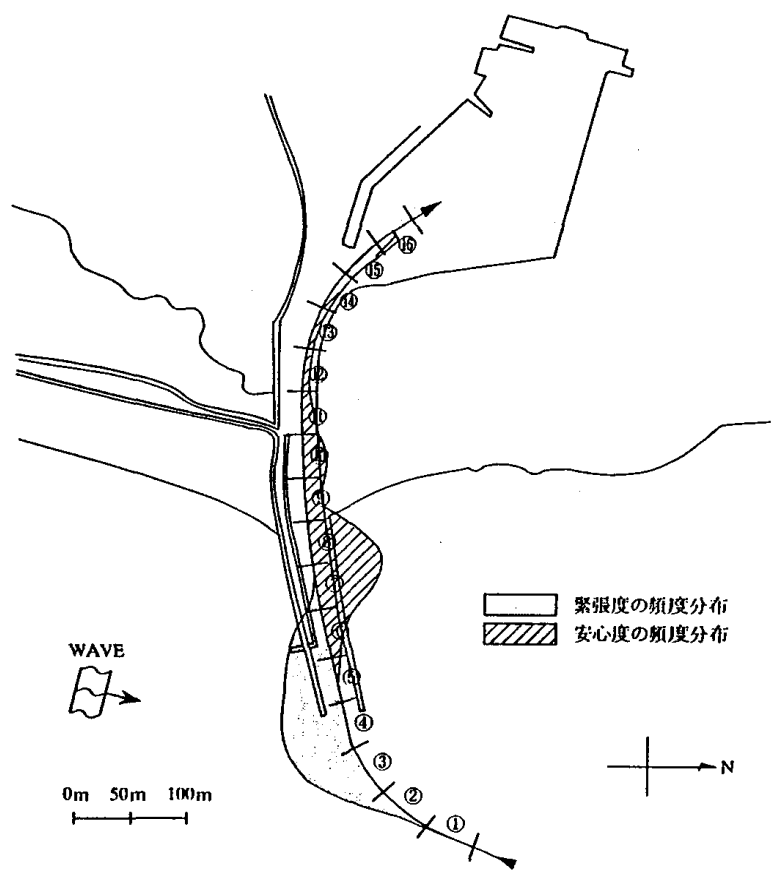

図 6 入港操船における緊張度と安心度 ( $A R$ 漁港の例) 


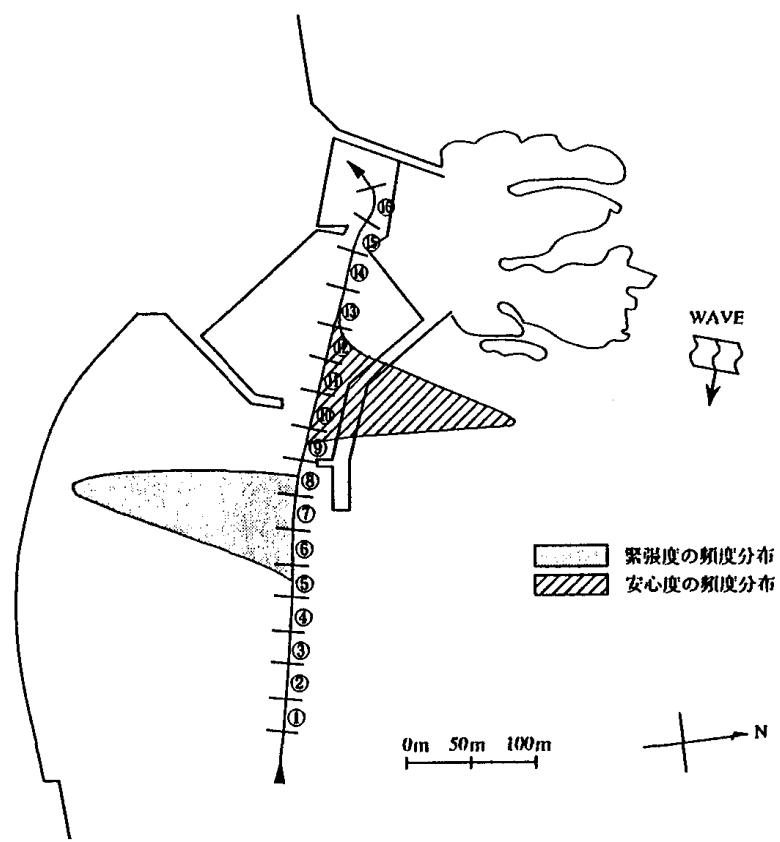

図 7 入港操船における緊張度と安心度 ( TP 漁港の例)

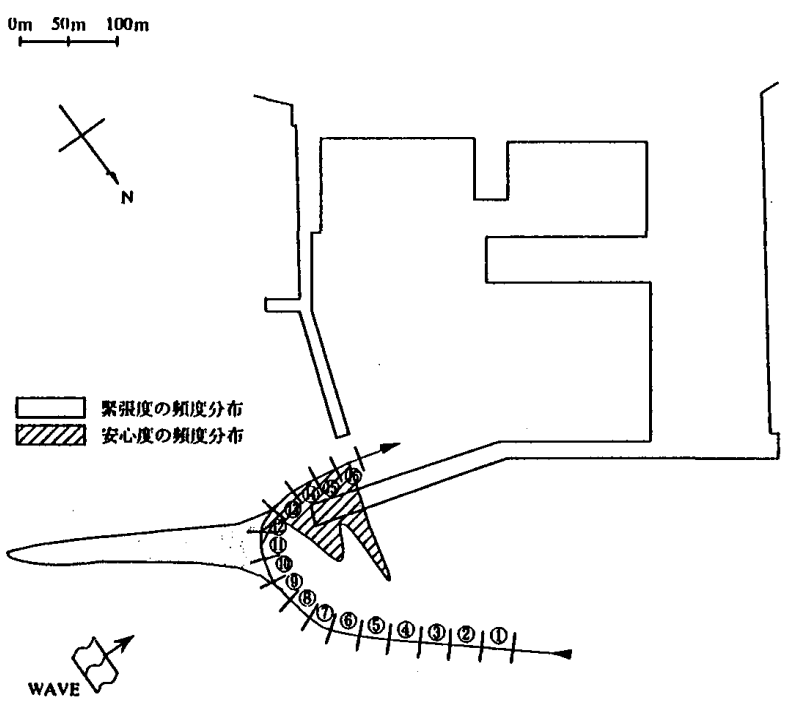

図 8 入港操船における緊張度と安心度 ( $T N$ 漁港の例)

\section{4 速力の分布}

\subsection{1 入港時の平均速力}

各漁港ごとの入港標準コースにおける速力変化の平均値はシケていない状態に比べ、シヶている状態で、 12 漁港中 9 港において減速運航（全ての位置番号において）を行っている。図 9 は太平洋に面した $N A$ 漁 港におけるアンケートを行ったコース上の位置とこの位置毎における回答速力の平均值の対応を表してい る。各漁港の入港標準コースと漁港事業計画平面図に記載されている波浪の激浪方向の関係より、9 漁港 は、激浪方向が正横〜船尾 (追い波状態) となり、シケの際に港口にいたるまでは波の状態を見ながら減 速している特性がよく現れている。

残りの 3 港においては、激浪方向が船首〜斜め前方 (向かい波状態) となり、シヶの際に増速を行い(全 部または一部の位置番号において)できるだけ短時間に狭い港口付近を通過しょうとする特性が見られる。

\section{4 .2 港口付近の速力分布}

シケの際に増速している 3 港を除いて、港口付近の速力は、図 10 及び図 11 の例に示すとおり、問題と している波浪中において累積相対度数が $0.1 \sim 0.9$ で約 $2 \sim 8$ ノット、累積相対度数 $0.2 \sim 0.8$ で約 $3.5 \sim 6$ ノットの範囲となる。従って港口付近をガイド配置点と仮定すると、設計速力は、減速パターンの 9 例か ら、波浪中の $90 \%$ 累積值を各漁港について求め、それらを平均し約 $5.5 / ッ ト$ 程度と見なすことができ る。なお、今回の調查で入港時の波浪方向が向かい波となるょうな漁港等においては、例外的に港口付近 の速力が 10 ノット以上となる場合す確認された。

図 10 及び図 11 は、シヶている状態とシケていない状態の回答速力分布の広がりの度合いの違いも示し ている。減速運航している 9 漁港いずれす、シヶて いる状態の速力分布の広がり度合いは、シヶていな い状態に比べ小さく、相対度数は集中する傾向にあ る。

\section{5 港口における運動エネルギー分布}

今回のアンケート結果により得られた漁船の質量 と港口付近での速力ょり各漁船の防波堤等の構造物 への衝突を想定した運動エネルギー $(E)$ の算定を 行った。運動エネルギー $(E)$ は式 (4)により算定し た。

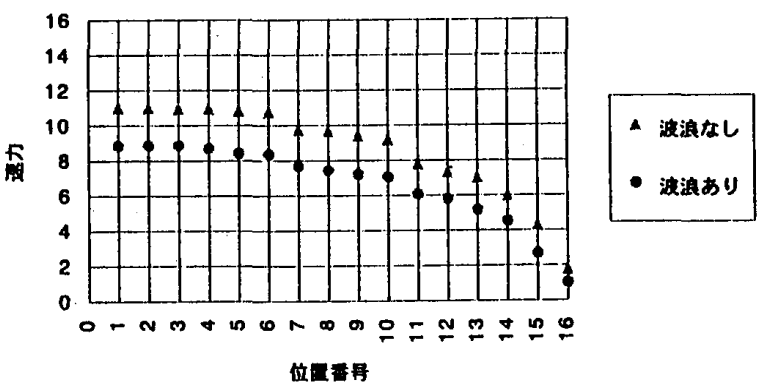

図 9 入港時の速力変化について ( $N A$ 漁港の例) 


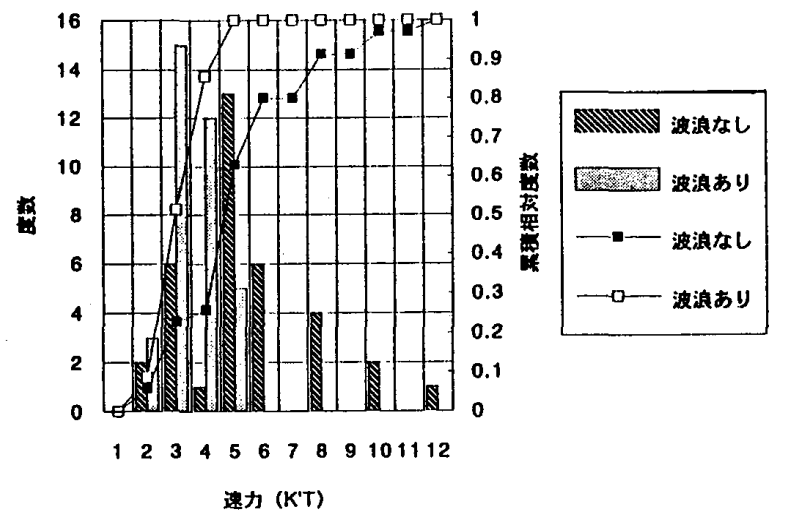

図 10 港口付近における速力分布 (SI 漁港の例)

$$
E=(1 / 2 \cdot g) \cdot(\alpha \cdot \Delta f) \cdot v^{2} \cdots \cdots(4)
$$

ここで、E：各漁船の運動エネルギー $(\mathrm{tf} \cdot \mathrm{m})$

\section{g : 重力加速度}

$\alpha$ : 見加け質量係数 ( $\alpha=1.1$ と仮定 $)$

$\triangle f:$ 船舶の満載排水量 $(\mathrm{tf})$

$v \quad$ : 港口の位置番号における速力

$v$ は回答された波浪中の速力のうち各漁港の港口 位置の速力ょり算定した。図 12 と図 13 は波浪中に おけるエネルギー分布の代表例で、横軸に運動エネ ルギーを縦軸に度数と累積相対度数で示している。 図 12 は波浪中減速運航をしている 9 港のうち最も 運動エネルギー分布の高い $K Z$ 漁港の例であり、図 13 は波浪中、例外的に増速運航している 3 港のう ち運動エネルギー分布の高いTP漁港の例である。 多くの漁港においてシケの際に港口付近で減速して いると予想できるので、図 12 の $K Z$ 漁港の事例は

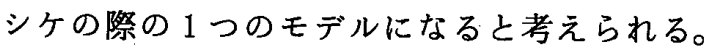

表 5 のエネルギー (1) は $\triangle f$ 及び $v$ のれぞれの 90\%累積値を用いて式(4)より求めたあのであり、 他方エネルギー(2) は、個々の回答データを基にし た運動エネルギー分布の $90 \%$ 累積值として求めた あのである。ガイドを設計する上で、全てを最大と すれば過大となることより、全ての漁船データを対 象とはできないので、このような $90 \%$ 累積值を求 めることにより各漁港毎の特性を検討することがで きる。なお、 $\triangle f$ は回答があまり得られなかったの

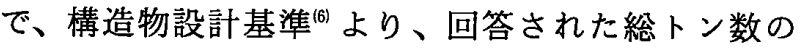
3 倍をとった。この表 5 より、減速運航している 9 漁港においては、運動エネルギーの $90 \%$ 累積值が 最大 $20 \mathrm{tf} \cdot \mathrm{m}$ 程度であることがわかる。

しかし、港口付近で、増速運航をしている漁港例 は、 $20 \mathrm{tf} \cdot \mathrm{m}$ 以上となっており、波浪中における各 漁港の運航形態に合わせてガイドの設計を行う必要 があることあ明らかになった。

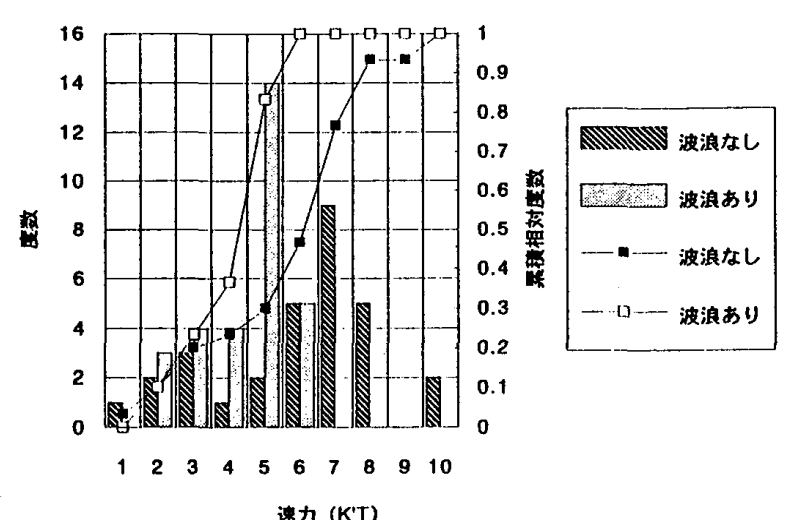

図 11 港口付近における速力分布 ( $N A$ 漁港の例)

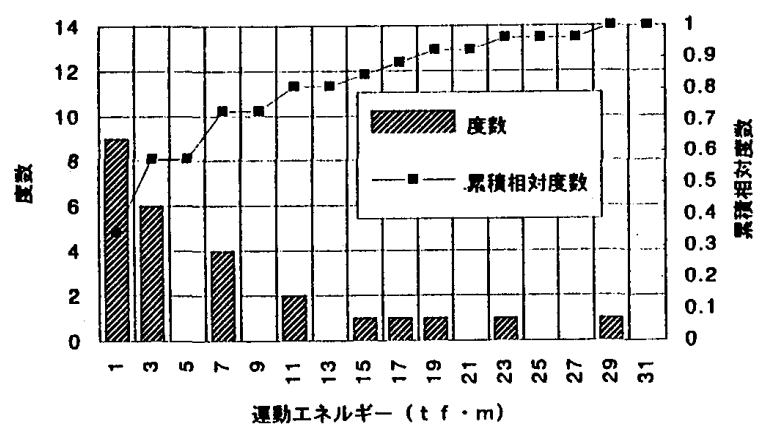

図 12 港口付近における波浪中の運動エネルギー 分布 $(K Z$ 漁港における減速入港の例)

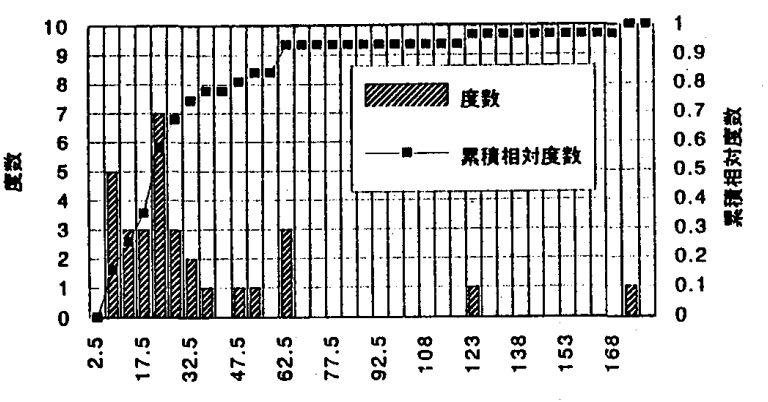

遇動エネルキー $(t f \cdot m)$

図 13 港口付近における波浪中の運動エネルギー 分布 (TP 漁港における増速入港の例)

表 5 各漁港の港口部における運動エネルギー の算定結果

\begin{tabular}{|c|c|c|c|c|c|}
\hline 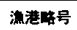 & 的トン数 (Ton) & 排水トンン数 (Ton) & 港口の遣力 (K'T) & エネルキーー(1) & エネルキー (2) \\
\hline si & 4.90 & 14.70 & 3.77 & 3.10 & 3.30 \\
\hline$\kappa z$ & 14.00 & 42.00 & 5.81 & 21.06 & 17.83 \\
\hline IP & 10.00 & 30.00 & 13.90 & 88.0 & 61.25 \\
\hline NS & 14.47 & 43.41 & 2.85 & 5.24 & 5.26 \\
\hline $\mathrm{AR}$ & 9,79 & 29,37 & 17.12 & $\quad 127: 80$ & $71: 43$ \\
\hline$T N$ & 13.65 & 40.95 & 3.18 & 6.15 & 9.20 \\
\hline NA & 10.00 & 30.00 & 5.00 & 11.14 & 9.54 \\
\hline 11 & 4.30 & 12.90 & 6.82 & 8.91 & 8.80 \\
\hline AO & 8.57 & 25.71 & 6.23 & 14.82 & 12.66 \\
\hline$r e$ & 11.43 & (34:29 & $\begin{aligned} 7,22 \\
\end{aligned}$ & 26.55 & 19.80 \\
\hline $\mathrm{KM}$ & 3.93 & 11.79 & 8.30 & 12.06 & 10.25 \\
\hline ND & 9.08 & 27.24 & 4.62 & 8.64 & 8.95 \\
\hline
\end{tabular}

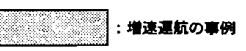

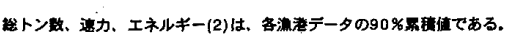


4.6 経験上の最大横傾 斜角について

図 14 は、代表的事例之 して、日本海沿岸の $S I$ 漁 港において回答者が経験し た最大横傾斜角についてま とめたものである。また、 表 6 は $20 \%$ 及び $50 \%$ 累積 值を各漁港毎に表したもの である。実務者が経験した 横傾斜角よりガイドの限界 横傾斜角の下限値として、 10\%累積值を求める予定で

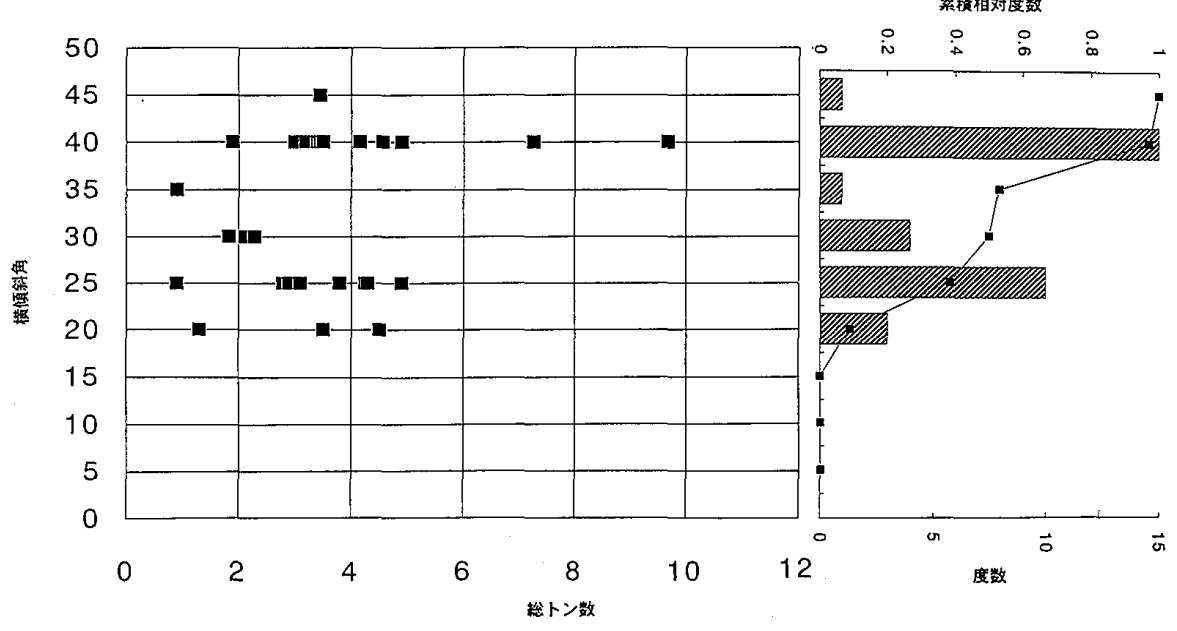

図 14 経験に基づく最大傾斜角について (SI 漁港の例) あったが $10 \%$ の回答比率以上の下限回答となった ので、20\%累積値を下限值として求めたものである。 経験に基づく全ての横傾斜角をカバーすることは、 ガイド設計を過大なものとする虘がある。そこで、 より設計条件の厳しくなる $20 \%$ 累積值は、ガイド の限界横傾斜角を決めるにあたって参考になると考 えられる。なお、50\%累積值は、参考として平均值 を示している。

\section{5. アンケート結果から見たガイド設計条件に ついて}

実務者は、4.1の調查結果より波浪中港口付近に おいて、小さい波で通過できるよう予測しながら運 航しており、このことはガイド設計時の対象波を決 定する上で、必ずしも最大波とする必要がない等参 考になると考えられる。

また、ガイドの設置場所は、4.3の調査結果より、 防波堤配置の複雑さ、変針動作の回数及び狭い港口 部の長さ等により、漁港の実情に即して検討する必 要が明らかになった。表 4 の算定で示した操船上の

表 6 各漁港の経験横傾斜角の累積値の算定結果

\begin{tabular}{|c|r|r|}
\hline 漁港略号 & 20\%累積値 & \multicolumn{1}{|c|}{$50 \%$ 累積値 } \\
\hline S I & 21.86 & 30.00 \\
\hline K & 16.09 & 26.74 \\
\hline T P & 16.67 & 19.26 \\
\hline N S & 26.67 & 31.48 \\
\hline A R & 18.15 & 27.04 \\
\hline TN & 21.30 & 25.22 \\
\hline N A & 10.00 & 21.85 \\
\hline I J & 25.55 & 28.88 \\
\hline A O & 30.00 & 37.77 \\
\hline Y & 20.15 & 28.33 \\
\hline KM & 16.67 & 20.85 \\
\hline N & 17.67 & 26.52 \\
\hline
\end{tabular}

緊張度の平均值、すなわち港口の手前約 $5 \sim 7 L$ の

位置は、ガイドの設置場所として参考になると考えられる。ガイドへの衝突速度及び吸収すべき運動エネ ルギーは、各漁港の運航形態より決定すべきである。すなわち、波浪中に減速運航しているか、增速運 航しているかにより異なるので、今後現地の速力観測等を実施し、漁港ごとの運航パターンを明らかに しながら、ガイドの設計を行う必要がある。さらに、4.6の調查結果より実務者が経験した最大横傾斜角 の累積値 $20 \%$ の下限值が得られたが、これらの值は漁船がガイドと接触した際の限界横傾斜の許容值を 決めるにあたって、一つの参考になると考えられる。しかしながら、この許容值は、今回得られた基礎 デー夕をもとに、定常風による船体傾斜や同調横摇れ等を想定した厳密な検討(7) 必要であろう。

\section{6. 結 語}

本研究では、ガイド試設計に役立てられるよう自然環境の厳しい漁港の入港問題に関連する内容・実務 者の入港操船の際の意識をアンケート調查を実施し、検討を加えた結果、以下のことが明らかとなった。 （1）入港できないと感ずる入港限界、すなわち限界風速、限界波高の感じ方は漁港ごとに多少異なる。 
（2）シケの際の港口付近の波の連なり方は、ほぼ規則性があり、操船者はシケになれば港口を小さい波 で通過できるように波の大小を予想しながら運航している。

（3）操船者は、風より波による入港時の問題を重要視しており、「波による保針困難」及び「波による船 体の傾斜」等による危険性を問題としている。

（4）緊張度、安心度の頻度分布は、主副防波堤配置のみの場合は、幅の狭い分布形状となり、港口付近 の波高低減のために主副以外の防波堤配置があれば、相当幅のある分布形状となる。このことは、操 船者の入港時の意識をよく表している。

（5）港口付近の速力分布は、シケの際に減速運航をしている漁港データより、累積相対度数 $0.1 \sim 0.9$ で 約 2〜8ノットの範囲、累積相対度数 $0.2 \sim 0.8$ で約 $3.5 \sim 6$ ノットの範囲である。

（6）港口付近の運動エネルギー分布は、減速運航を行う漁港の最む高い事例の $90 \%$ 累積值で約 $20 \mathrm{tf} \cdot \mathrm{m}$ と推定できる。例外的に増速運航している事例では、さらに高い運動エネルギーとなる。

（7）実務者の経験上の最大横傾斜角が得られた。これは、漁船がガイドと接触した際の横傾斜の許容値を 決める上での参考になる。

最後に本調查を行うにあたり多大な御協力を頂いた各漁業協同組合、実務者の方々及び漁船のデー夕に ついて貴重な御意見をご教示いただいた株式会社新鳰鉄工所、近藤氏に感謝の意を表する次第である。

\section{参 考 文 献}

（1） 久保雅義・斎藤勝彦・大音宗昭：漁船の入港援助施設に関する基礎的研究, 海岸工学論文集, 第 37 巻, pp. $728 \sim 732,1990$ 年.

（2）久保雅義・斎藤勝彦・岡田 学・下田直克：漁港用ネット式船舶入港支援ガイドに関する実験的研究, 海岸工学論文集, 第 38 巻, pp.756 760, 1991 年.

（3）久保雅義・斎藤勝彦・上田 茂・岡田 学・下田直克：入港支援ガイド接触時の船体運動について, 日本航海学会論文集, 86 号, pp. 251 259, 1992 年.

（4）久保雅義・斎藤勝彦・上田 茂・岡田 学・下田直克：横傾斜の低減を目的とした船舶入港支援ガイ ドの構造改善について, 海岸工学論文集, 第 39 巻, pp.1066 1070, 1992 年.

(5) 久保雅義・斎藤勝彦・岡田 学：漁船の入港問題の現状について, 日本航海学会論文集, 87 号, pp. $39 \sim 46,1992$ 年.

（6）全国漁港協会編：漁港構造物標準設計法, pp. 53～54，1992 年.

（7） 天下井 清：漁船の海難と安全対策，航海，第 87 号，pp.84〜89，1986 年.

\section{質 疑 応 答}

井上欣三 (神戸商船大学)：防波堤配置と操船者の感じる緊張感の対応図についてお尋ねします。

(1)アンヶートの中で回答者が感ずる緊張感は、何に対して感ずる緊張なのでしょうか?

(2) 私共が、提案している三次元視覚モデルによる結果と今回のアンケート結果とは、一致が見られま す。あし、アンヶートの回答者が答えた緊張感が操船水域の制約に基づくものであれば、著者らが提案 しているガイドは、さらに操船水域を制約することになり、操船者に与える緊張感は、より高まると いった逆効果の懸念がありませんか?この面からの検討は、なされているのでしょうか?

水井 真治：(1)アンヶートで回答をお願いした緊張感は、シヶの際にどの位置番号で、実務者が最も操 船上負担を感ずるかを設問しています。従って、どのような要因についての緊張感かといった具体的想 定はしておりません。しかしながら、実務者が問題としているのは、狭い港口付近の精神的負担を種々 の要因から感じているようであり、水域の狭さに対する緊張感に近い回答結果であろうと考えます。

(2) 自然環境の厳しい漁港においては、風波の遮蔽を考えて、防波堤の建設のみで対応しているのが現 状です。防波堤周囲は消波ブロックが設置されており、これはかなり緩やかに水中に広がっています。 このため、実際の可航幅は見える幅よりかなり狭いのが実情です。その結果、図 5、図 6 の事例のよう に港口が狭くなり、操船者はいつまです緊張状態がつづくことになります。著者らは、ガイドの設置に より、こうした入港時の問題をハード面から具体的に解決する提案をしております。なお、防波堤組み 込み式ガイドは、エネルギー吸収のために必要な変位は $2 \mathrm{~m}$ 程度想定しており、現状の可航幅には影響 
を与えません。

石田廣史 (神戸商船大学)：(1) シケの状態について、アンケート時にその判断基準等があるのでしょう か?

(2) 漁協ごとに操業基準等があり、シケ状態の入港操船に、各漁港ごとの違いがアンケート回答にバラ ッキとして入っているのでしょうか? 以上の 2 点について、お教え下さい。

水井真治：(1)『シヶの状態』とは、『入港できる限界に近い波高がある状態』と説明を行い、アンケート を行いました。

(2) ご指摘のあった各漁港におうる操業基準、帰港の基準等、小型漁船が利用する漁港においては、ほ とんどの場合ないことを確認しております。つまり、小型漁船の操業中止等の判断は、ほとんど実務者 に委ねられているのが実情です。従って、入港出来ないと感ずる限界風速及び限界波高等は、地域外力 特性及び漁船の種類等によりバラッキが存在しているのではないかと考えます。 